\title{
Cryopreservation of Hematopoietic Stem Cells: Emerging Assays, Cryoprotectant Agents, and Technology to Improve Outcomes
}

\author{
Kathlyn Hornberger ${ }^{b}$ Guanglin $\mathrm{Yu}^{\mathrm{a}}$ David McKenna ${ }^{\mathrm{c}}$ Allison Hubel ${ }^{\mathrm{a}}$ \\ ${ }^{a}$ Department of Mechanical Engineering, University of Minnesota, Minneapolis, MN, USA; ${ }^{b}$ Department of \\ Biomedical Engineering, University of Minnesota, Minneapolis, MN, USA; ' Department of Laboratory Medicine and \\ Pathology, University of Minnesota, Minneapolis, MN, USA
}

\section{Keywords}

Cryopreservation $\cdot$ Hematopoietic stem cells · Storage · Dimethyl sulfoxide $\cdot$ Freezing

\begin{abstract}
Hematopoietic stem cell (HSC) therapy is widely used to treat a growing number of hematological and non-hematological diseases. Cryopreservation of HSCs allows for cells to be transported from the site of processing to the site of clinical use, creates a larger window of time in which cells can be administered to patients, and allows sufficient time for quality control and regulatory testing. Currently, HSCs and other cell therapies conform to the same cryopreservation techniques as cells used for research purposes: cells are cryopreserved in dimethyl sulfoxide (DMSO) at a slow cooling rate. As a result, HSC therapy can result in numerous adverse symptoms in patients due to the infusion of DMSO. Efforts are being made to improve the cryopreservation of HSCs for clinical use. This review discusses advances in the cryopreservation of HSCs from 2007 to the present. The preclinical development of new cryoprotectants and new technology to eliminate cryoprotectants after thawing are discussed in detail. Additional cryopreservation considerations are included, such as cooling rate, storage temperature, and cell concentration. Preclinical cell assessment and quality control are discussed, as well as clinical studies from the past decade that focus on new cryopreservation protocols to improve patient outcomes.

(C) 2019 S. Karger AG, Basel
\end{abstract}

\section{Introduction}

Since the first transplantation of bone marrow in the 1950s [1], hematopoietic stem cell transplantation (HSCT) has been successfully implemented as a treatment for patients with hematologic cancers, such as leukemia and lymphoma, and congenital or acquired diseases of the hematopoietic system such as sickle cell disease $[2,3]$. According to the Worldwide Network for Blood and Marrow Transplantation (WBMT), one million HSCTs had been performed by the end of 2012 [4]. In addition to conventional uses of HSCT for the treatment of hematologic malignancies, clinical uses have expanded in recent years to include treatment of severe scleroderma [5], diabetes [6], metabolic disorders [7], and even delivery of gene therapy $[7,8]$.

There are three major sources of hematopoietic stem cells (HSCs), including bone marrow harvested by aspiration from the cavity of the ilium (hipbone), peripheral blood obtained through leukapheresis, and umbilical cord blood (UCB) collected from the placenta after childbirth [9]. HSCT can be performed with either autologous HSCs (obtained from the patient) or allogenic HSCs (obtained from a donor), and both types of HSCs come with certain advantages and disadvantages. Autologous HSCs are free of the clinical risks of rejection and graft-versushost disease (GVHD); however, for hematologic cancer treatment, autologous bone marrow or peripheral blood may contain residual cancer cells, which could result in

\section{KARGER}

(C) 2019 S. Karger AG, Basel 
relapse [2]. The major drawback of allogeneic HSCT is GVHD, which results in potentially very severe and lifethreatening skin, gut, and liver disease. Allogeneic HSCT also may lead to delays in immune reconstitution, which can result in increased rates of infection, treatment-related mortality, and chronic GVHD [9-11]. Successful allogeneic HSCT also significantly relies on the availability of an appropriate donor source. For patients without matched siblings or relatives, finding a human leukocyte antigen-matching donor can be challenging and time consuming.

Cryopreservation of HSCs allows for more effective treatment of patients. Fresh HSCs, once harvested, are only viable for several hours to a few days, limiting their geographical reach. Frozen cells can be transported from the site of processing to a clinical site, extending both the geographical reach of viable cells and the genetic diversity of cells available to patients. Freezing cells greatly extends their shelf life and allows for more rigorous quality controls and testing, resulting in improved safety of HSC therapy. Despite these benefits, the cryopreservation of HSCs poses several challenges, most notably a decline in cell viability after thawing and adverse reactions in patients due to cryoprotectants used.

This review discusses advancements in the cryopreservation of HSCs from 2007 to the present. Readers interested in advancements in HSC cryopreservation prior to 2007 should read the review by Fleming et al. [12]. For a comprehensive review of the history of HSC cryopreservation, readers can see reviews by Sputtek et al. [13-15]. In addition, a 2014 review focuses on detailed methods of cryoprotectant removal for cell therapies [16]. In this review, new cryoprotectants and new technologies are discussed, as well as additional factors of the freezing process such as cell concentration, stability of cryopreserved cells, and cooling rate. Preclinical cell assessment is included as well as recent clinical studies involving HSCs cryopreserved using emerging methods.

\section{New Cryoprotectants}

Cryopreservation solutions are specialized solutions that contain additives, more commonly known as cryoprotectants, that help cells survive the stresses of freezing and thawing. Dimethyl sulfoxide (DMSO) is the current gold standard for cell cryopreservation and is the most commonly used cryoprotectant for HSCs. The cryoprotective action of DMSO results from specific molecular interactions. Water and DMSO interact strongly and these interactions result in unique behavior during freezing [17]. For example, solutions of water and DMSO have far lower freezing points than the pure constituents. Molecular dynamic simulations suggest that DMSO alters the structure and function of the cell membrane producing pores at sufficient concentrations [18]. In addition, as a low-molecular-weight cryoprotectant, DMSO has colligative properties, meaning that the presence of DMSO molecules in the solution depresses the freezing point [19].

However, DMSO may be unsuitable for cryopreservation of cells intended for human use due to its toxicity in patients, resulting in a wide range of adverse events. In mice, the LD50 of intraperitoneal injections of $25 \%$ DMSO is $15.4 \mathrm{~g} / \mathrm{kg}$ [20]. In humans, a recent review article found numerous DMSO-related side effects, ranging from cardiac arrest and respiratory stress to epileptic seizures [21]. Multiple studies have noted adverse patient reactions following infusion of DMSO-preserved HSCs, ranging from mild events like nausea and vomiting to life-threatening conditions such as cardiac arrhythmia [22-24].

A simple way of decreasing adverse reactions to DMSO infusion is to use lower concentrations of DMSO. A 2013 preclinical study, followed by two clinical trials, looked at three DMSO concentrations (10, 7.5, and 5\%) for cryopreservation of HSCs [25-27]. Preclinical results showed a decrease in nucleated cell recovery for concentrations of DMSO below $10 \%$, but found the highest number of colonies formed from cells frozen in 7.5\% DMSO [25]. A subsequent clinical study compared 7.5 and 10\% DMSO among two groups of patients. Reduction of DMSO resulted in faster leukocyte recovery, but the frequency of adverse events was unchanged between the two groups [26]. In the following 2018 clinical study, autologous peripheral blood stem cell (PBSC) transplants of cells frozen at all three DMSO concentrations were performed in 150 patients [27]. In this study, reduction in DMSO concentration had no impact on engraftment, but adverse reactions such as nausea, fever, and tachycardia were lowest in patients who received cells that had been frozen in 5\% DMSO [27]. These results suggest that decreasing the concentration of DMSO to $5 \%$ could become the new standard in HSC cryopreservation.

Another method for DMSO reduction involves decreasing the amount of DMSO and adding another component. A study by Hayakawa et al. [28] used 5\% DMSO and $5 \%$ pentastarch in the cryopreservation of UCB. Cells in $5 \% \mathrm{DMSO}$ with pentastarch had higher post-thaw viability than cells frozen in 10\% DMSO [26]. McCullough et al. [29] explored the use of hydroxyethyl starch (HES) mixed with DMSO at different ratios to enhance cryopreservation of PBSCs. Sputtek et al. [30] found that 5\% DMSO in the presence of 6\% HES is sufficient for cryopreservation of peripheral blood progenitor cells. In similar studies, HES and dextran have been mixed with DMSO to improve the cryopreservation outcome of HSCs [28, 31-33]. Chen et al. [31] compared cryopreser- 
vation of UCB under multiple conditions, including $10 \%$ ethylene glycol and 2\% DMSO, $10 \%$ DMSO with $2 \%$ dextran, and $2.5 \% \mathrm{DMSO}$ with $30 \mathrm{mmol} / \mathrm{L}$ trehalose. Postthaw comparison of cell viability, colony-forming units (CFUs), and apoptosis found 2.5\% DMSO with trehalose to be most successful at maintaining the differentiation potential and cell viability.

There is considerable interest in the development of alternatives to DMSO. Studies suggest that sugars interact directly with the cell membrane during freezing [34, 35]. The addition of sugars to solutions containing DMSO also results in changes in ice patterns that are observed [36]. Sugars such as trehalose and sucrose have gained popularity in the cryopreservation of HSCs and satisfying cryopreservation outcomes have been broadly demonstrated. Trehalose and sucrose have been evaluated to preserve HSCs from UCB and have achieved similar results to those preserved in $10 \%$ DMSO solution in terms of the clonogenic potential of progenitor cells, cell viability, and numbers of CD45+/33+ cells [37]. The use of $0.3 \mathrm{M}$ sucrose with 5\% DMSO resulted in a better functional capacity of hematopoietic stem and progenitor cells compared to those cryopreserved in 10\% DMSO with $10 \%$ fetal bovine serum [38]. Cryopreservation of PBSCs with only trehalose showed improved cell survival compared to cells cryopreserved in 10\% DMSO with $90 \%$ fetal bovine serum [39].

In addition to its benefits as an extracellular cryoprotectant, trehalose can be transported into cells to further its cryoprotective potential. Trehalose, a disaccharide of glucose, is approved for human use and has been demonstrated to have no adverse symptoms up to $50 \mathrm{~g}$ delivered orally [40]. As trehalose is membrane impermeable, methods of active loading of trehalose into cells using trehalose-containing liposome or cell surface receptor have been developed to increase the preservation outcome of human blood cells [41] and hematopoietic stem/progenitor cells during lyophilization [42]. A study of cord blood cryopreservation observed the benefits of trehalose both inside and outside the cell by transporting it across the cell membrane via liposome. Post-thaw viability by 7-aminoactinomycin D (7-AAD) showed that the optimal post-thaw survival occurred for cells frozen with both intra- and extracellular trehalose as well as 2.5\% DMSO. However, intra- and extracellular trehalose without DMSO also showed high viability, equivalent to the current standard of $10 \%$ DMSO [43].

Changing ice pattern formation can influence the freezing response. As a result, there is interest in molecules that alter the freezing of water. Several small-molecule ice recrystallization inhibitors (IRIs) have been demonstrated as effective cryoprotectants for HSCs and UCB [44, 45]. IRIs are carbon-linked antifreeze glycoprotein analogues. IRIs were capable of reducing the average ice crystal size and a positive correlation between smaller ice crystal size and increased post-thaw function of HSCs was validated [44]. Another category of molecule that has been studied is Rho-kinase-associated inhibitor. This molecule acts on the Rho-kinase pathway, which plays a role in a wide range of cellular phenomena but principally the function of the cytoskeleton. It is worth mentioning that ROCK inhibitor Y-27632 should be used with caution for the cryopreservation of HSCs. Although ROCK inhibitor Y-27632 has been demonstrated to enhance the survival of human embryonic stem cells following cryopreservation [46], other studies have discovered that ROCK inhibitor Y-27632 negatively affects the expansion/survival of both fresh and cryopreserved cord blood-derived CD34+ hematopoietic progenitor cells [47].

The studies described above demonstrate interest in the development of alternatives to DMSO for the preservation of HSCs. As we understand more about cryoprotective agents and the manner by which they act, our ability to develop alternatives to DMSO increases. Ideally, a replacement to DMSO would maintain high levels of post-thaw recovery, be non-toxic to cells, and reduce or eliminate adverse reactions in recipients of the cells. These characteristics would improve the workflow and safety of HSC-based products.

\section{New Technology}

Removal of DMSO from cryopreserved HSCs before infusion could reduce the adverse effects of HSCT. The classical method of DMSO removal is based on the centrifugation of immediately thawed cell products [48]. Cells are centrifuged, the supernatant is removed and replaced with fresh solution, and the process is repeated. Traditional washing is labor-intensive and results in cell loss [12], but has been shown to reduce DMSO-related toxicity in patients. A study conducted by Akkök et al. [49] found that patients who received autografts that were manually washed experienced significantly fewer adverse effects, but platelet engraftment time increased by 2 days. Several commercially available washing devices such as CytoMate $^{\mathrm{TM}}$, Sepax $^{\mathrm{TM}}$, and Lovo have been developed to automate the washing procedure, and high recovery of viable CD34+ cells with good engraftment potential after automated washing has been demonstrated in various studies using these washing devices [50-54].

Other than well-established washing devices, new methods of DMSO removal without dependence on centrifugation are being developed, including filtration by spinning membrane [16], DMSO extraction through diffusion in microfluidic channels $[55,56]$, and dilution through hollow-fiber membranes [57]. Spinning membrane filtration allows for cell suspension to undergo vol- 
ume reduction and end in a reduced volume of fresh solution [50]. While there is a low risk of contamination with this method, it can be expensive and cells are lost due to clumping [16]. Microfluidics can be used to remove DMSO from small samples using parallel streams of a cell suspension and a wash solution [12]. This method works well for small volumes but is difficult to scale up [16]. For larger cell volumes, hollow fiber membranes can be used for DMSO removal. Hollow fiber devices consist of a large cylindrical tube filled with thousands of thin hollow fibers. To remove DMSO from a cell suspension, the suspension flows through the thin fibers, while a washing solution flows through the larger tube in the opposite direction. DMSO is then transported out of cells and washed away [57].

While washing may be a good alternative for patients with a history of DMSO toxicity, additional problems may arise. Conventional, centrifuge-based methods for washing are time-consuming, result in cell losses which can prolong platelet engraftment, and pose a risk of cell contamination $[27,49,58]$. To alleviate these issues, alternatives to washing include freezing cells in a lower concentration of DMSO or diluting the thawed product before infusion.

\section{Additional Considerations}

Due to the issue of DMSO toxicity in patients who receive cell therapies, the majority of research in HSC cryopreservation focuses on reducing or removing DMSO from cryoprotectant solutions. Additional factors that impact the success of HSC cryopreservation include the freezing rate, pre-freeze storage conditions, cell concentration, and storage temperature. A brief review of these parameters is included in this section.

\section{Freezing Rate}

Cryopreservation of HSCs is generally carried out using slow cooling rates (approx. $1^{\circ} \mathrm{C} / \mathrm{min}$ ). A comparison between slow cooling $\left(2^{\circ} \mathrm{C} / \mathrm{min}\right)$ and rapid cooling (vitrification) of human UCB cells has been performed by Djuwantono et al. [59], who found that cell viability and CD34+ enumeration after rapid cooling was significantly higher than that after slow cooling. These results suggest that rapid cooling is a promising cryopreservation method for UCB.

\section{Precooling}

Since the addition of DMSO to HSCs causes an exothermic reaction, there is concern that this release of energy could cause damage to cells. Dijkstra-Tiekstra et al. [60] performed a study using precooled DMSO and precooled white blood cells (WBCs). Results showed that precooling has a minimal effect on WBC recovery. It was determined that $50 \%$ precooled DMSO performed better than $20 \%$ precooled DMSO, and a slow cooling rate performed better than fast freezing, but differences were minimal.

\section{Pre-Freeze Storage}

Delays in cryopreservation after the collection of cells may adversely affect cell viability [61]. A study by Guttridge et al. [61] found that pre-cryopreservation storage time significantly affected the viability of CD34+ cells from UCB after cryopreservation, suggesting that extended pre-cryopreservation should be avoided. This finding is consistent with results of another study by Schwandt et al. [62], which showed that the highest viability for cord blood cells was obtained when cells were cryopreserved directly after collection. The temperature at which cells are stored before freezing may also affect the cryopreservation outcome. It is also suggested that hematopoietic progenitor cells should be maintained at a refrigerated temperature $\left(4-8^{\circ} \mathrm{C}\right)$ before freezing to avoid significant losses in cell potency $[63,64]$.

\section{Cell Concentration}

Cell concentration is an important parameter that requires careful consideration before freezing, as a low cell concentration is associated with more DMSO usage, higher cost, and greater patient toxicity. Despite these factors, the influence of cell concentration on cryopreservation outcome is not well studied [65]. Two studies have demonstrated that cryopreservation of PBSCs at a concentration of $2 \times 10^{8}$ cells $/ \mathrm{mL}$ still yielded high recovery of viable cells [66] and excellent engraftment after autologous PBSC transplantation [65]. An earlier study even indicated a cell concentration of $3.7 \pm 1.9 \times 10^{8}$ for cryopreservation of PBSCs did not result in loss of engraftment potential [67]. It is noteworthy that a cell concentration that is too high may lead to cell loss and cell clumping after thawing, or seizures during the infusion of cells. As a result, special care should be taken with high cell concentration products $[68,69]$.

\section{Storage Temperature}

Controlled-rate freezing and storage in vapor nitrogen has been a standard technique for cryopreservation of HSCs. To explore and validate easier and more cost-effective ways of cryopreservation of HSCs, freezing and storage of cells in a $-80^{\circ} \mathrm{C}$ mechanical freezer has been examined. However, the recovery rate and viability of CD34+ cells were significantly decreased for PBSCs cryopreserved for 10 years with this method, although the myeloid differentiation potential, in vivo reconstitution, and self-renew potential of CD34+ cells were maintained [70]. Loss of CD34+ cells was even observed for HSCs cryopre- 
served by non-controlled rate freezing and stored at $-80^{\circ} \mathrm{C}$ overnight [71]. Calvet et al. [72] found that hematopoietic and immunologic reconstitution with PBSCs cryopreserved at $-80^{\circ} \mathrm{C}$ for less than 6 months is satisfactory, although a profound CD34+ T lymphocyte deficit persists at 1 year. Sputtek et al. [73] compared the recovery of PBSCs frozen at $-80^{\circ} \mathrm{C}$ versus $-170^{\circ} \mathrm{C}$ for 3 and 6 months and found that $-80^{\circ} \mathrm{C}$ storage resulted in significant loss of cell membrane integrity and clonogenic potential. Encouraging results from one study found that hematopoietic recovery for PBSCs was found not adversely affected by long storage ( $>1$ year) at $-80^{\circ} \mathrm{C}$, which was demonstrated at two independent centers using similar freezing and storage techniques [74]. Yuan et al. [75] found success at stabilizing pluripotent stem cells for up to 1 year at $-80^{\circ} \mathrm{C}$ by adding the minimally toxic polysaccharide Ficoll 70 to their cryoprotectant solution.

These studies suggest that this easier and cheaper method might be valuable in areas where the access to liquid nitrogen and controlled-rate freezing is limited. Although rare, malfunction or failure of the controlledrate freezing device is a potential risk. One interesting study examined the effects of interruptions of controlledrate freezing on the viability of umbilical cord cells in order to provide guidance of the proper response in case of freezing device failure [76]. There was no difference in post-thaw survival between the temperature at which cooling was interrupted if cells were transferred to a $-80^{\circ} \mathrm{C}$ freezer; however, cells should only be transferred to vapor nitrogen when the interrupting temperature was lower than $-40^{\circ} \mathrm{C}$.

\section{Long-Term Storage}

Some of the earliest UCB was harvested and frozen in the 1990s. There is interest in determining the shelf life of frozen HSCs after long-term storage. The ability to bank cells for an extended time allows for greater flexibility in treatment options and availability. Seo et al. [77] compared cord blood samples preserved for 1 and 2 years. Total nucleated cell count (TNC), cell viability, and CD34+ count showed no significant difference between cells frozen for 1 and 2 years, although as expected, both showed a decrease in viability and CD34+ cell count compared to fresh samples. Lee et al. [78] extended this range of successful cord blood storage, finding no significant difference in TNC, cell viability, and CD34+ count for cells frozen up to 5 years.

A clinical study by Lisenko et al. [79] found that the storage duration of PBSCs did not impact patient hematopoietic recovery for storage times ranging from several months to several years. The quality of long-term cryopreserved UCB units for HSCT showed no difference between cells cryopreserved for 10 years and 1 month, in terms of percentage of viable cells, CD34+CD38- cells, and CD34+CXCR4+ cells [80]. Hematopoietic progenitor cells cryopreserved in 5 and $10 \%$ DMSO for $<1$ year, 1-9 years, and $>9$ years showed no difference in viability [81]. No difference in time to WBC engraftment or to platelet engraftment between the three storage groups ( $<1$ year, $1-9$ years, and $>9$ years) was observed. Longterm storage ( $>60$ months) of PBSCs in vapor phase nitrogen after controlled rate freezing also did not have a negative effect on hematopoietic recovery [79]. However, in another study, total nucleated cell count, CD34+ cell count, and cell viability for cells from peripheral blood or bone marrow cryopreserved for 11-19 years was found to decrease with time [82].

One study by Broxmeyer et al. [83] found that CD34+ cells from UCB that had been frozen for up to 21 years were able to be engrafted in mice. This finding suggests that HSCs can recover and maintain their self-renewing potential years after cryopreservation and long-term storage. Hubel et al. [84] imposed a storage lesion on cryopreserved UCB by storing them at $-80^{\circ} \mathrm{C}$. They observed that conventional markers of UCB viability, including nucleated cell count, CFUs, and enumeration of CD34+ cells, showed little sensitivity to the storage lesion. However, apoptosis markers such as caspases were upregulated rapidly after imposition of the storage lesion. In another arm of this study, UCB frozen for approximately 1 year was compared to UCB frozen for more than 11 years. Little difference was observed in these cells as a result of different storage times [84], Overall, it seems that long-term storage for less than 10 years does not significantly affect cryopreservation outcome.

\section{Preclinical Assays for Quality}

Determining the quality of HSCs after freezing and thawing typically involves flow cytometric analysis to determine cell viability and cell type, as well as further viability analysis such as CFU and TNC. Flow cytometry allows for the identification of viable cells using a viability dye such as 7-AAD, which binds DNA and is excluded by cells with an intact cell membrane. Cell type can be determined using antibodies that bind to CD34, a cell surface marker for blood and bone marrow-derived stem cells [85]. Clinically, this test has limited applications, since the CD34 count is usually determined before freezing and is not reflective of the cells post-thaw [86]. TNC is used to determine the total number of cells that contain a nucleus and is commonly used to determine cell quality and likelihood of engraftment prior to infusion [86]. CFU, considered to be the best measure of viable stem cells, is a measure of how cells divide and form colonies over time. In 2011, Page et al. [86] determined CFU to be a robust measure of engraftment following UCB transplant. 


\section{Post-Thaw Assessment}

Traditionally, the assessment of PBSC grafts before infusion into patients is made before cells are frozen and thawed. Before freezing, the total number of CD34+ cells is determined, and this number is used post-thaw to determine the total cell number administered to the patient. In a 2008 study by Lee et al. [87], PBSCs were analyzed via flow cytometry of 7-AAD and CD34 after collection from 36 patients and immediately post-thaw. Thawed PBSCs were administered to patients and the time to engraftment was determined by daily blood counts. The results indicated that quantification of the viable CD34+ cell number is a more accurate predictor of engraftment than the pre-freeze viable cell count. Similarly, Page et al. [86] performed a cord blood transplant study and found that measuring CD34+ and TNC before cryopreservation was not a good reflection of post-thaw engraftment success. Predicting engraftment success is most accurate when cells are analyzed post-thaw.

\section{Preclinical Functionality}

Post-thaw viability does not guarantee post-thaw cell functionality. In 2016, Morgenstern et al. [88] found several instances of patients with delayed engraftments despite sufficient post-thaw viability of CD34+ cells. Determining post-thaw functionality is thus an important step before moving into clinical trials. Cell functionality can be determined by CFU, as performed by Chevaleyre et al. [89] in a study of UCB, which found that storing UCB for 3 days at $4{ }^{\circ} \mathrm{C}$ prior to cryopreservation increased functionality.

Animal models can also be used for preclinical assessment. As previously mentioned, Broxmeyer et al. [83] found successful engraftment of UCB cryopreserved for over 20 years in mice. In 2016, Yang et al. [90] successfully demonstrated the functionality of bone marrow mononuclear cells post-thaw in a rodent stroke model. Mice were induced with ischemic stroke and received fresh or thawed bone marrow mesenchymal stem cells. Thawed cells had previously been frozen in liquid nitrogen for 12 months. Although flow cytometry results showed decreased viability in the thawed cells, mouse recovery from stroke was comparable between the fresh and thawed cells [90].

\section{Clinical Studies}

Currently, most clinical studies that focus on cryopreservation of HSCs concentrate on DMSO reduction, post-thaw DMSO removal, and assessment of long-term cell storage. As previously mentioned in this review, a 2014 and subsequent 2018 clinical trial had success in decreasing adverse reactions in patients by decreasing the
DMSO concentration [27], while a study by Akkök et al. [49] found that washing samples prior to infusion decreased patient side effects. Similarly, Foïs et al. [91] found a reduction in adverse side effects when washing cells before infusion. Galmes et al. [92] developed a simple technique for PBSC cryopreservation. Cells were stored at $-80^{\circ} \mathrm{C}$ without the use of a control rate freezer. Both 5 and 10\% DMSO samples were tested. Patients who received cells frozen in 5\% DMSO had higher platelet recovery and decreased infusion-related toxicity.

As previously mentioned in this review, Calvet et al. [72] developed an unconventional method for cryopreservation of hematopoietic progenitor cells that involves passive freezing to $-80^{\circ} \mathrm{C}$ with only $3.5 \% \mathrm{DMSO}$. A clinical study of 342 autografts after storage for 3, 6, and 12 months was performed, and engraftment success and long-term immunological reconstitution was observed. Results showed this method to be successful for up to 6 months of storage time. A decade-long clinical study performed by Pavlů et al. [93] observed hematopoietic recovery after transplant in 50 patients. Patients received two transplants for myeloma treatment at least 2 years apart, and no reduction in patient recovery was observed as a result of longer cell storage. A study by Mitchell et al. [94] tracked UCB transplants with varying storage times in liquid nitrogen ranging from several months to 11 years. Their analysis found that storage time had no impact on engraftment up to 11 years.

Although currently there are few clinical studies that focus on cryopreservation of HSCs, results have been promising. Reducing DMSO in cryoprotectants or washing cells prior to infusion has shown success at decreasing patient adverse reactions. Clinical trials focusing on cell storage time have shown cells can be stored for up to 11 years without impacting therapeutic potential.

\section{Conclusion}

Optimal cryopreservation of HSCs requires the consideration of several factors, including composition of the cryoprotectant solution, cell concentration, freezing rate, and storage temperatures. Much of the research in this area focuses on the cryoprotectant solution used. To date, DMSO remains the gold standard for cryopreservation of HSCs, despite evidence of detrimental side effects experienced by patients. In the past decade, efforts have been made to reduce, wash away, or eliminate DMSO in cryoprotectant solutions. Multiple clinical studies have shown success at reducing the amount of DMSO used in cryoprotectant solutions from $10 \%$ to as low as $3.5 \%$. Additional clinical studies have shown that washing cells prior to infusion into patients can decrease DMSO-related side effects. Preclinical experiments have indicated prelimi- 
nary success of DMSO-free solutions, but these results have yet to be demonstrated in clinical research. Quality control studies have found HSCs to be stable in liquid nitrogen for up to 10 years, with cells frozen up to 11 years showing clinical success. Clinical results have also highlighted the importance of post-thaw cell assessment to predict engraftment success.

As HSC therapy and other emerging cell therapies grow in popularity, there is a need for improvement in HSC cryopreservation protocols. The successful development and widespread use of optimized DMSO-free or reduced solutions is a crucial step in improving HSCT. In addition, it is important that clinical cell assessment is performed on thawed cells rather than relying on prefreeze data, since freezing and thawing impacts cell quality. Overall, improving HSC cryopreservation standards and protocols would result in fewer patient side effects, improved safety and quality control, and enhanced efficacy of HSC therapy as well as other emerging cell therapies.

\section{Disclosure Statement}

The authors declare that they have no competing interests.

\section{References}

1 Thomas ED, Lochte HL Jr, Lu WC, Ferrebee JW. Intravenous infusion of bone marrow in patients receiving radiation and chemotherapy. N Engl J Med. 1957 Sep;257(11):491-6.

2 Chabannon C, Kuball J, Bondanza A, Dazzi F, Pedrazzoli P, Toubert A, et al. Hematopoietic stem cell transplantation in its 60s: A platform for cellular therapies. Sci Transl Med. 2018 Apr;10(436):1-11.

3 Bhatia M, Sheth S. Hematopoietic stem cell transplantation in sickle cell disease: patient selection and special considerations. J Blood Med. 2015 Jul;6:229-38.

4 Gratwohl A, Pasquini MC, Aljurf M, Atsuta Y, Baldomero H, Foeken L, et al.; Worldwide Network for Blood and Marrow Transplantation (WBMT). One million haemopoietic stem-cell transplants: a retrospective observational study. Lancet Haematol. 2015 Mar; 2(3):e91-100.

5 Sullivan KM, Goldmuntz EA, Keyes-Elstein L, McSweeney PA, Pinckney A, Welch B, et al.; SCOT Study Investigators. Myeloablative autologous stem-cell transplantation for severe scleroderma. N Engl J Med. 2018 Jan; 378(1):35-47.

6 Malmegrim KC, de Azevedo JT, Arruda LC, Abreu JR, Couri CE, de Oliveira GL, et al. Immunological balance is associated with clinical outcome after autologous hematopoietic stem cell transplantation in type 1 diabetes. Front Immunol. 2017 Feb;8:167.

7 Domen J, Gandy K, Dalal J. Emerging uses for pediatric hematopoietic stem cells. Pediatr Res. 2012 Apr;71(4 Pt 2):411-7.

8 Bordignon C, Roncarolo MG. Therapeutic applications for hematopoietic stem cell gene transfer. Nat Immunol. 2002 Apr;3(4):318-21.

9 Barriga F, Ramírez P, Wietstruck A, Rojas N. Hematopoietic stem cell transplantation: clinical use and perspectives. Biol Res. 2012; 45(3):307-16

10 Ferrara JL, Levine JE, Reddy P, Holler E. Graft-versus-host disease. Lancet. 2009 May; 373(9674):1550-61.

11 Bejanyan N, Brunstein CG, Cao Q, Lazaryan A, Luo X, Curtsinger J, et al. Delayed immune reconstitution after allogeneic transplantation increases the risks of mortality and chronic GVHD. Blood Adv. 2018 Apr;2(8): 909-22.
12 Fleming Glass K, Longmire E, Hubel A. Optimization of a microfluidic device for diffusion-based extraction of DMSO from a cell suspension. Int J Heat Mass Transfer. 2009;6: 247-53.

13 Sputtek A, Gutensohn K, Hummel K, Loliger C, Kuhnl P. Zur Kryokonsevierung von Blutstammzellen. J Lab Med. 1996;20:70-7.

14 Sputtek A. Kryokonservierung von Blutzellen und hämatopoetischen Stammzellen. In: Kiefel V, editor. Transfusionsmedizin und Immunhämatologie. Berlin: Springer; 2010. p. 123-31.

15 Sputteck A, Skubinn R. Cryopreservation in transfusion medicine and hematology. In: Life in the Frozen State. Boca Raton: CRC Press; 2004. p. 483-504.

16 Shu Z, Heimfeld S, Gao D. Hematopoietic SCT with cryopreserved grafts: adverse reactions after transplantation and cryoprotectant removal before infusion. Bone Marrow Transplant. 2014 Apr;49(4):469-76.

17 Luzar A, Chandler D. Structure and hydrogen bond dynamics of water-dimethyl sulfoxide mixtures by computer simulations. J Chem Phys. 1993;98(10):8160-73.

18 Gurtovenko AA, Anwar J. Modulating the structure and properties of cell membranes: the molecular mechanism of action of dimethyl sulfoxide. J Phys Chem B. 2007 Sep; 111(35):10453-60.

19 Rowley SD. Hematopoietic stem cell cryopreservation: a review of current techniques. J Hematother. 1992;1(3):233-50.

20 Worthley EG, Schott CD. The toxicity of four concentrations of DMSO. Toxicol Appl Pharmacol. 1969 Sep;15(2):275-81.

21 Cox MA, Kastrup J, Hrubiško M. Historical perspectives and the future of adverse reactions associated with haemopoietic stem cells cryopreserved with dimethyl sulfoxide. Cell Tissue Bank. 2012 Jun;13(2):203-15.

22 Cordoba R, Arrieta R, Kerguelen A, Hernandez-Navarro F. The occurrence of adverse events during the infusion of autologous peripheral blood stem cells is related to the number of granulocytes in the leukapheresis product. Bone Marrow Transplant. 2007 Dec; 40(11):1063-7.
23 Donmez A, Tombuloglu M, Gungor A, Soyer N, Saydam G, Cagirgan S. Clinical side effects during peripheral blood progenitor cell infusion. Transfus Apheresis Sci. 2007 Feb;36(1): 95-101.

24 Zenhäusern R, Tobler A, Leoncini L, Hess OM, Ferrari P. Fatal cardiac arrhythmia after infusion of dimethyl sulfoxide-cryopreserved hematopoietic stem cells in a patient with severe primary cardiac amyloidosis and endstage renal failure. Ann Hematol. 2000 Sep; 79(9):523-6.

25 Smagur A, Mitrus I, Giebel S, SadusWojciechowska M, Najda J, Kruzel T, et al. Impact of different dimethyl sulphoxide concentrations on cell recovery, viability and clonogenic potential of cryopreserved peripheral blood hematopoietic stem and progenitor cells. Vox Sang. 2013 Apr;104(3):240-7.

26 Mitrus I, Smagur A, Giebel S, Gliwinska J, Prokop M, Glowala-Kosinska M, et al. A faster reconstitution of hematopoiesis after autologous transplantation of hematopoietic cells cryopreserved in $7.5 \%$ dimethyl sulfoxide if compared to $10 \%$ dimethyl sulfoxide containing medium. Cryobiology. 2013 Dec; 67(3):327-31.

27 Mitrus I, Smagur A, Fidyk W, Czech M, Prokop M, Chwieduk A, et al. Reduction of DMSO concentration in cryopreservation mixture from $10 \%$ to $7.5 \%$ and $5 \%$ has no impact on engraftment after autologous peripheral blood stem cell transplantation: results of a prospective, randomized study. Bone Marrow Transplant. 2018 Mar;53(3): 274-80.

28 Hayakawa J, Joyal EG, Gildner JF, Washington KN, Phang OA, Uchida N, et al. 5\% dimethyl sulfoxide (DMSO) and pentastarch improves cryopreservation of cord blood cells over 10\% DMSO. Transfusion. 2010 Oct; 50(10):2158-66.

29 McCullough J, Haley R, Clay M, Hubel A, Lindgren B, Moroff G. Long-term storage of peripheral blood stem cells frozen and stored with a conventional liquid nitrogen technique compared with cells frozen and stored in a mechanical freezer. Transfusion. 2010 Apr; 50(4):808-19. 
30 Sputtek A, Jetter S, Hummel K, Loliger C, Kuhnl P. Interaction of HES/DMSO concentration and cooling rate on the recovery of cryopreserved human PBSC [abstract]. Cryobiology. 1996;33:650-1.

31 Chen G, Yue A, Ruan Z, Yin Y, Wang R, Ren $\mathrm{Y}, \mathrm{Zhu}$ L. Comparison of the effects of different cryoprotectants on stem cells from umbilical cord blood. Stem Cells Int. 2016;2016: 1396783.

32 Rowley SD, Feng Z, Chen L, Holmberg L, Heimfeld S, MacLeod B, et al. A randomized phase III clinical trial of autologous blood stem cell transplantation comparing cryopreservation using dimethylsulfoxide vs dimethylsulfoxide with hydroxyethylstarch Bone Marrow Transplant. 2003 Jun;31(11): 1043-51.

33 Liu KY, Dong WC, Wang YL, Jiang YJ, Gao ZY, Huang NW, et al. [Study on non-programmed process using dimethyl sulfoxide and hydroxyethyl starch as cryoprotectants in cryopreservation of cord blood hematopoietic cells]. Zhongguo Shi Yan Xue Ye Xue Za Zhi. 2004 Oct;12(5):670-3. Chinese.

34 Crowe JH, Crowe LM, Carpenter JF, Rudolph AS, Wistrom CA, Spargo BJ, Anchordoguy TJ. Interactions of sugars with membranes. Biochim Biophys Acta. 1988 Jun;947(2):36784.

$35 \mathrm{Yu} \mathrm{G}, \mathrm{Li}$ R, Hubel A. Interfacial interactions of sucrose during cryopreservation detected by Raman Spectroscopy. Langmuir. doi: 10.1021/acs.langmuir.8b01616. Epub 2018 Nov 14.

36 Bailey TL, Wang M, Solocinski J, Nathan BP, Chakraborty N, Menze MA. Protective effects of osmolytes in cryopreserving adherent neuroblastoma (Neuro-2a) cells. Cryobiology. 2015 Dec;71(3):472-80.

37 Rodrigues JP, Paraguassú-Braga FH, Carvalho L, Abdelhay E, Bouzas LF, Porto LC. Evaluation of trehalose and sucrose as cryoprotectants for hematopoietic stem cells of umbilical cord blood. Cryobiology. $2008 \mathrm{Apr}$; 56(2):144-51.

38 Petrenko YA, Jones DR, Petrenko AY. Cryopreservation of human fetal liver hematopoietic stem/progenitor cells using sucrose as an additive to the cryoprotective medium. Cryobiology. 2008 Dec;57(3):195-200.

39 Martinetti D, Colarossi C, Buccheri S, Denti G, Memeo L, Vicari L. Effect of trehalose on cryopreservation of pure peripheral blood stem cells. Biomed Rep. 2017 Mar;6(3):314-8.

40 Abbott PJ, Chen J. WHO Food Additives Series 46: Trehalose safety evaluation of certain food additives and contaminants. Geneva: WHO; 2001. p. 998.

41 Holovati JL, Gyongyossy-Issa MI, Acker JP Effects of trehalose-loaded liposomes on red blood cell response to freezing and post-thaw membrane quality. Cryobiology. 2009 Feb; 58(1):75-83.

42 Buchanan SS, Pyatt DW, Carpenter JF. Preservation of differentiation and clonogenic potential of human hematopoietic stem and progenitor cells during lyophilization and ambient storage. PLoS One. 2010 Sep;5(9): $1-11$.
43 Motta JP, Paraguassú-Braga FH, Bouzas LF, Porto LC. Evaluation of intracellular and extracellular trehalose as a cryoprotectant of stem cells obtained from umbilical cord blood. Cryobiology. 2014 Jun;68(3):343-8.

44 Briard JG, Poisson JS, Turner TR, Capicciotti CJ, Acker JP, Ben RN. Small molecule ice recrystallization inhibitors mitigate red blood cell lysis during freezing, transient warming and thawing. Sci Rep. 2016 Mar;6(1):23619.

45 Wu LK, Tokarew JM, Chaytor JL, von Moos E, Li Y, Palii C, et al. Carbohydrate-mediated inhibition of ice recrystallization in cryopreserved human umbilical cord blood. Carbohydr Res. 2011 Jan;346(1):86-93.

46 Watanabe K, Ueno M, Kamiya D, Nishiyama A, Matsumura M, Wataya T, et al. A ROCK inhibitor permits survival of dissociated human embryonic stem cells. Nat Biotechnol. 2007 Jun;25(6):681-6.

47 Bueno C, Montes R, Menendez P. The ROCK inhibitor Y-27632 negatively affects the expansion/survival of both fresh and cryopreserved cord blood-derived CD34+ hematopoietic progenitor cells: Y-27632 negatively affects the expansion/survival of CD34+HSPCs. Stem Cell Rev. 2010 Jun;6(2): 215-23.

48 Rubinstein P, Dobrila L, Rosenfield RE, Adamson JW, Migliaccio G, Migliaccio AR, et al. Processing and cryopreservation of placental/ umbilical cord blood for unrelated bone marrow reconstitution. Proc Natl Acad Sci USA. 1995 Oct;92(22):10119-22.

49 Akkök ÇA, Holte MR, Tangen JM, Østenstad $\mathrm{B}$, Bruserud O. Hematopoietic engraftment of dimethyl sulfoxide-depleted autologous peripheral blood progenitor cells. Transfusion. 2009 Feb;49(2):354-61.

50 Calmels B, Drezet A, Huynh C, Autret A, Stoppa AM, Bouabdallah R, et al. Automated washing of autologous hematopoietic stem cell grafts after thawing does not impair engraftment. Bone Marrow Transplant. 2014 Aug;49(8):1127-8.

51 Mfarrej B, Bouchet G, Couquiaud J, Regimbaud L, Binninger S, Mercier M, et al. Preclinical assessment of the Lovo device for dimethyl sulfoxide removal and cell concentration in thawed hematopoietic progenitor cell grafts. Cytotherapy. 2017 Dec;19(12):1501-8.

52 Aerts-Kaya F, Koca G, Sharafi P, Sayla FÇ, Uçkan-Çetinkaya D, Özdemir E. Automated washing of long-term cryopreserved peripheral blood stem cells promotes cell viability and preserves CD34+ cell numbers. Bone Marrow Transplant. 2018 Sep;53(9):1225-7.

53 Sánchez-Salinas A, Cabañas-Perianes V, Blanquer M, Majado MJ, Insausti CL, Monserrat J, et al. An automatic wash method for dimethyl sulfoxide removal in autologous hematopoietic stem cell transplantation decreases the adverse effects related to infusion. Transfusion. 2012 Nov;52(11):2382-6.

54 Abonnenc M, Pesse B, Tissot JD, Barelli S, Lion N. Automatic washing of thawed haematopoietic progenitor cell grafts: a preclinical evaluation. Vox Sang. 2017 May;112(4): 367-78.

55 Hubel A. Advancing the preservation of cellular therapy products. Transfusion. 2011 Nov;51(Suppl 4):82-6.
56 Hanna J, Hubel A, Lemke E. Diffusion-based extraction of DMSO from a cell suspension in a three stream, vertical microchannel. Biotechnol Bioeng. 2012 Sep;109(9):2316-24.

57 Ding W, Zhou X, Heimfeld S, Reems JA, Gao D. A steady-state mass transfer model of removing CPAs from cryopreserved blood with hollow fiber modules. J Biomech Eng. 2010 Jan;132(1):011002.

58 Lecchi L, Giovanelli S, Gagliardi B, Pezzali I, Ratti I, Marconi M. An update on methods for cryopreservation and thawing of hemopoietic stem cells. Transfus Apheresis Sci. 2016 Jun; 54(3):324-36

59 Djuwantono T, Wirakusumah FF, Achmad TH, Sandra F, Halim D, Faried A. A comparison of cryopreservation methods: slow-cooling vs. rapid-cooling based on cell viability, oxidative stress, apoptosis, and CD34+ enumeration of human umbilical cord blood mononucleated cells. BMC Res Notes. 2011 Sep;4(1):371.

60 Dijkstra-Tiekstra MJ, Setroikromo AC, Kraan M, Gkoumassi E, de Wildt-Eggen J. Optimization of the freezing process for hematopoietic progenitor cells: effect of precooling, initial dimethyl sulfoxide concentration, freezing program, and storage in vapor-phase or liquid nitrogen on in vitro white blood cell quality. Transfusion. 2014 Dec;54(12):315563.

61 Guttridge MG, Soh TG, Belfield H, Sidders C, Watt SM. Storage time affects umbilical cord blood viability. Transfusion. 2014 May;54(5): 1278-85.

62 Schwandt S, Liedtke S, Kogler G. The influence of temperature treatment before cryopreservation on the viability and potency of cryopreserved and thawed CD34+ and CD45+ cord blood cells. Cytotherapy. 2017 Aug;19(8):962-77.

63 Fry LJ, Giner SQ, Gomez SG, Green M, Anderson S, Horder J, et al. Avoiding room temperature storage and delayed cryopreservation provide better postthaw potency in hematopoietic progenitor cell grafts. Transfusion. 2013 Aug;53(8):1834-42.

64 Seo JY, Huh HJ, Park HK, Choung HK, Kim DW, Koo HH, et al. Evaluation of overnight storage conditions for autologous peripheral blood stem cell products: comparison of three different conditions. Vox Sang. 2012 Aug; 103(2):150-8.

65 Félix OM, Tunes G, Ginani VC, Simões PC, Barros DP, Delbuono E, et al. The influence of cell concentration at cryopreservation on neutrophil engraftment after autologous peripheral blood stem cell transplantation. Hematol Transfus Cell Ther. 2018 Jul-Sep;40(3): 233-9.

66 Alencar S, Garnica M, Luiz RR, Nogueira CM, Borojevic R, Maiolino A, et al. Cryopreservation of peripheral blood stem cell: the influence of cell concentration on cellular and hematopoietic recovery. Transfusion. $2010 \mathrm{Nov}$; 50(11):2402-12.

67 Rowley SD, Bensinger WI, Gooley TA, Buckner CD. Effect of cell concentration on bone marrow and peripheral blood stem cell cryopreservation. Blood. 1994 May;83(9):2731-6. 
68 Bachier C, Potter J, Potter G, Sugay R, Shaughnessy $\mathrm{P}$, Chan $\mathrm{K}$, et al. High white blood cell concentration in the peripheral blood stem cell product can induce seizures during infusion of autologous peripheral blood stem cells. Biol Blood Marrow Transplant. 2012 Jul; 18(7):1055-60.

69 Villalón L, Odriozola J, Ramos P, Ramos ML Herrera P, de Oteyza JP. Cryopreserving with increased cellular concentrations of peripheral blood progenitor cells: clinical results. Haematologica. 2002 Feb;87(2):ELT06.

70 Shima T, Iwasaki H, Yamauchi T, Kadowaki M, Kiyosuke M, Mochimaru T, et al. Preserved in vivo reconstitution ability of PBSCs cryopreserved for a decade at $-80^{\circ} \mathrm{C}$. Bone Marrow Transplant. 2015 Sep;50(9):1195200.

71 Donmez A, Yilmaz F, Soyer N, Cagirgan S, Arik B, Tombuloglu M. The loss of CD34+ cells in peripheral hematopoietic stem cell products cryopreserved by non-controlled rate freezing and stored at $-80^{\circ} \mathrm{C}$ after overnight storage. Transfus Apheresis Sci. 2014 Oct;51(2):188-92.

72 Calvet L, Cabrespine A, Boiret-Dupré N, Merlin E, Paillard C, Berger M, et al. Hematologic, immunologic reconstitution, and outcome of 342 autologous peripheral blood stem cell transplantations after cryopreservation in a $-80^{\circ} \mathrm{C}$ mechanical freezer and preserved less than 6 months. Transfusion. 2013 Mar;53(3):570-8.

73 Sputtek A, Rowe AW, Kuhnl P. Long-term storage of peripheral blood progenitor cells at $-80^{\circ} \mathrm{C}$ leads to a pronounced decrease of the clonogenic potential compared to $-170^{\circ} \mathrm{C}$ storage in the vapor phase over liquid nitrogen. Cryobiology. 2005;51:355.

74 Detry G, Calvet L, Straetmans N, Cabrespine A, Ravoet C, Bay JO, et al. Impact of uncontrolled freezing and long-term storage of peripheral blood stem cells at $-80^{\circ} \mathrm{C}$ on haematopoietic recovery after autologous transplantation. Report from two centres. Bone Marrow Transplant. 2014 Jun;49(6):780-5.

75 Yuan Y, Yang Y, Tian Y, Park J, Dai A, Roberts RM, et al. Efficient long-term cryopreservation of pluripotent stem cells at $-80^{\circ} \mathrm{C}$. Sci Rep. 2016 Oct;6(1):34476.

76 Yang H, Pidgorna A, Loutfy MR, Shuen P. Effects of interruptions of controlled-rate freezing on the viability of umbilical cord blood stem cells. Transfusion. 2015 Jan;55(1):70-8.
77 Seo SH, Shin S, Roh EY, Song EY, Oh S, Kim $\mathrm{BJ}$, et al. Long-term quality control program plan for cord blood banks in Korea: A pilot study for cryopreservation stability. Ann Lab Med. 2017 Mar;37(2):124-8.

78 Lee HR, Song EY, Shin S, Roh EY, Yoon JH, Kim BJ. Quality of cord blood cryopreserved for up to 5 years. Blood Res. 2014 Mar;49(1): 54-60.

79 Lisenko K, Pavel P, Kriegsmann M, Bruckner T, Hillengass J, Goldschmidt H, et al. Storage Duration of Autologous Stem Cell Preparations Has No Impact on Hematopoietic Recovery after Transplantation. Biol Blood Marrow Transplant. 2017 Apr;23(4):684-90.

80 Yamamoto S, Ikeda H, Toyama D, Hayashi M, Akiyama K, Suzuki M, et al. Quality of long-term cryopreserved umbilical cord blood units for hematopoietic cell transplantation. Int J Hematol. 2011 Jan;93(1):99-105.

81 Veeraputhiran M, Theus JW, Pesek G, Barlogie B, Cottler-Fox M. Viability and engraftment of hematopoietic progenitor cells after long-term cryopreservation: effect of diagnosis and percentage dimethyl sulfoxide concentration. Cytotherapy. 2010 Oct;12(6):764-

82 Fernyhough LJ, Buchan VA, McArthur LT, Hock BD. Relative recovery of haematopoietic stem cell products after cryogenic storage of up to 19 years. Bone Marrow Transplant. 2013 Jan;48(1):32-5.

83 Broxmeyer HE, Lee MR, Hangoc G, Cooper S, Prasain N, Kim YJ, et al. Hematopoietic stem/progenitor cells, generation of induced pluripotent stem cells, and isolation of endothelial progenitors from 21- to 23.5-year cryopreserved cord blood. Blood. 2011 May; 117(18):4773-7.

84 Hubel A, Spindler R, Curtsinger JM, Lindgren B, Wiederoder S, McKenna DH. Postthaw characterization of umbilical cord blood: markers of storage lesion. Transfusion. 2015 May;55(5):1033-9.

85 Sutherland DR, Anderson L, Keeney M, Nayar R, Chin-Yee I; International Society of Hematotherapy and Graft Engineering. The ISHAGE guidelines for CD34+ cell determination by flow cytometry. J Hematother. 1996 Jun;5(3):213-26.

86 Page KM, Zhang L, Mendizabal A, Wease S, Carter S, Gentry T, et al. Total colony-forming units are a strong, independent predictor of neutrophil and platelet engraftment after unrelated umbilical cord blood transplantation: a single-center analysis of 435 cord blood transplants. Biol Blood Marrow Transplant. 2011 Sep;17(9):1362-74.
87 Lee S, Kim S, Kim H, Baek EJ, Jin H, Kim J, et al. Post-thaw viable CD34(+) cell count is a valuable predictor of haematopoietic stem cell engraftment in autologous peripheral blood stem cell transplantation. Vox Sang. 2008 Feb;94(2):146-52.

88 Morgenstern DA, Ahsan G, Brocklesby M, Ings $\mathrm{S}$, Balsa $\mathrm{C}$, Veys $\mathrm{P}$, et al. Post-thaw viability of cryopreserved peripheral blood stem cells (PBSC) does not guarantee functional activity: important implications for quality assurance of stem cell transplant programmes. Br J Haematol. 2016 Sep;174(6):942-51.

89 Chevaleyre J, Rodriguez L, Duchez P, Plainfossé M, Dazey B, Lapostolle V, et al. A novel procedure to improve functional preservation of hematopoietic stem and progenitor cells in cord blood stored at $+4^{\circ} \mathrm{C}$ before cryopreservation. Stem Cells Dev. 2014 Aug;23(15): 1820-30.

90 Yang B, Parsha K, Schaar K, Satani N, Xi X, Aronowski J, Savitz SI. Cryopreservation of bone marrow mononuclear cells alters their viability and subpopulation composition but not their treatment effects in a rodent stroke model. Stem Cells Int. 2016;2016:5876836.

91 Foïs E, Desmartin M, Benhamida S, Xavier F, Vanneaux V, Rea D, et al. Recovery, viability and clinical toxicity of thawed and washed haematopoietic progenitor cells: analysis of 952 autologous peripheral blood stem cell transplantations. Bone Marrow Transplant. 2007 Nov;40(9):831-5.

92 Galmes A, Gutiérrez A, Sampol A, Canaro M, Morey M, Iglesias J, et al. Long-term hematological reconstitution and clinical evaluation of autologous peripheral blood stem cell transplantation after cryopreservation of cells with $5 \%$ and $10 \%$ dimethylsulfoxide at -80 degrees $\mathrm{C}$ in a mechanical freezer. Haematologica. 2007 Jul;92(7):986-9.

93 Pavlů J, Auner HW, Szydlo RM, Sevillano B, Palani R, O'Boyle F, et al. Analysis of hematopoietic recovery after autologous transplantation as method of quality control for long-term progenitor cell cryopreservation. Bone Marrow Transplant. 2017 Dec;52(12):1599-601.

94 Mitchell R, Wagner JE, Brunstein CG, Cao Q, McKenna DH, Lund TC, et al. Impact of longterm cryopreservation on single umbilical cord blood transplantation outcomes. Biol Blood Marrow Transplant. 2015 Jan;21(1): 50-4. 